\title{
Migration behaviour of Atlantic salmon smolts (Salmo salar L.) in a short and highly fragmented gravel-bed river stretch
}

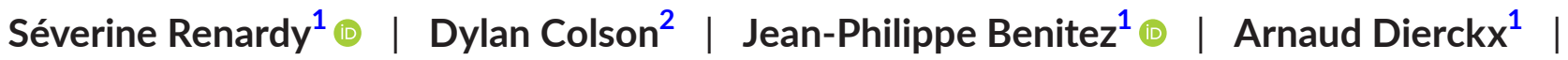 \\ Delphine Goffaux $^{2}$ | Justine Sabbe ${ }^{2}$ | Amaury Rabouan ${ }^{2}$ | Olivier Detrait ${ }^{3}$ |

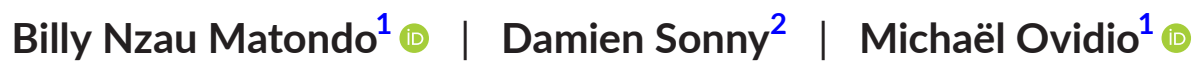

${ }^{1}$ UR-FOCUS, Management of Aquatic Resources and Aquaculture Unit, Laboratory of Fish Demography and Hydroecology, University of Liège, Liège, Belgium

${ }^{2}$ Profish Technology S.A., Assesse, Belgium

${ }^{3}$ Public Service of Wallonia, DDRCB DCENN, Jambes, Belgium

Correspondence

Séverine Renardy, University of Liège, UR-FOCUS, Management of Aquatic Resources and Aquaculture Unit, Laboratory of Fish Demography and Hydroecology, Liège, Belgium.

Email: severine.renardy@uliege.be

Funding information

Service Public de Wallonie; Fonds pour la Formation à la Recherche dans I'Industrie et dans l'Agriculture

\begin{abstract}
The succession of migration barriers and different turbine types during downstream migration impede Atlantic salmon (Salmo salar L.) smolts from reaching the sea in time but is poorly studied. We investigated the isolated and cumulative impacts of 14 consecutive migration barriers (MBs) on downstream migration of 200 radio-tagged smolts over an $18.9 \mathrm{~km}$ stretch of gravel-bed river, by equipping five MBs with automated radio listening stations. At the level of isolated barriers, median research times (i.e. time between the first and the last detection upstream of a MB) varied between 0.1 and $0.7 \mathrm{~h}$. The median crossing delays (i.e. time between the first detection upstream and the first detection downstream of a MB) varied between 1 and $2.9 \mathrm{~h}$. Considering successive MBs, median cumulative crossing delays varied between 2.6 and $32.1 \mathrm{~h}$ and increased with the number of MBs. We observed a global mortality rate between $33 \%$ and $76 \%$, increasing with the distance travelled and the associated number of MBs. Only $48 \%$ of the migrating smolts reached the end of the studied river stretch. Results suggest that the dynamics of the smolt downstream migration over this short highly fragmented stretch had a significant effect in terms of delays, mortalities and seaward escapement rate.
\end{abstract}

KEYWORDS

Archimedes screw, behavioural tactic, hydraulics, hydroelectricity, migration barrier, mortality

\section{1 | INTRODUCTION}

For several decades, rivers have been fragmented to enable manmade activities, such as hydropower production and water regulation (Nilsson et al., 2005). These disruptions have caused drastic reductions, and even the extinction of several entire populations of some migratory species, such as the Atlantic salmon (Salmo salar L.) (Parrish et al., 1998), by impeding free movement (Katopodis \& Williams, 2012) and limiting and preventing access to functional habitats (Fullerton et al., 2010). The Atlantic salmon is one of the most sensitive species due to its complex life cycle, including both marine and freshwater migrations (McCormick et al., 1998). To enable the reintroduction of the Atlantic salmon, several mitigation facilities have been set up to re-establish free movement at hydropower stations (Katopodis \& Williams, 2012). Significant progress has been made in improving upstream movements of spawning salmon. On the contrary, the performance of mitigation measures is still insufficient to facilitate a safe and quick passage of the downstreammigrating smolts (Fjeldstad et al., 2018; Williams et al., 2012) and to enable a sufficient seaward escape rate (Renardy et al., 2021). 
Confrontation with hydropower stations during the downstream migration causes delays in finding a safe and attractive migration route (Renardy et al., 2020) but also causes injuries and direct and indirect mortality due to energy expenditure (Marschall et al., 2011; Renardy et al., 2021), predation (Koed et al., 2002) and passage through turbines (Coutant \& Whitney, 2000).

Numerous measures have been implemented, such as behavioural and physical barriers (Scruton et al., 2003; Tomanova et al., 2021), downstream bypasses (Ovidio et al., 2021) and improved hydropower station management (Szabo-Meszaros et al., 2019). Fish-friendly turbines (e.g. the Archimedes screw) have been also developed to ensure safe passage (Hogan et al., 2014) due to low rotational speed, large blade spacing and the absence of extreme pressure change (Cefas, 2012). However, contrary to other mitigation measures, little attention has been given to the behavioural response of fish approaching these structures and the implications in terms of delay, attraction and efficiency.

All these measures may mitigate the negative impact of one specific hydropower station and increase successful passage (Fjeldstad et al., 2018). However, during downstream migration, smolts travel long distances in rivers and face numerous migration barriers (MBs), some of which are unequipped with fish protection systems. In spite of mitigation measures, the cumulative impact of successive MBs on downstream migration may still be significant (Thorstad et al., 2012). Renardy et al. (2021) highlighted an escape rate of $8 \%$ in a river stretch with only two hydropower stations. Studies focus mainly on the impact of isolated hydropower stations (Havn et al., 2017; Kärgenberg et al., 2020; Moore et al., 2018; Ovidio et al., 2021; Stich et al., 2014; Thorstad et al., 2017), but little attention has been paid to the cumulative impact (Havn et al., 2020; Holbrook et al., 2011; Newton et al., 2019). In those studies, smolt tracking was performed mainly at the end of the downstream-migration process in largesized lowland river stretches of 50-100 km in length. In Belgium, small and medium-sized gravel-bed rivers, where the migration process begins, are highly fragmented over short distances, which may induce a considerable effect on the success of the migration further downstream.

In this study, we investigated the downstream migratory behaviour of Atlantic salmon smolts over 14 consecutive migration barriers (eight weirs and six hydropower stations) along the Vesdre river by using radio telemetry. The first aim was to evaluate the specific delays at each isolated MB and the associated passage failure. We hypothesised significant delays and passage failure caused by the MBs. The second aim was to assess the cumulative impact of these $\mathrm{MBs}$ on the downstream migratory behaviour of the smolts in terms of (a) migration delays, (b) mortality rate, and (c) escape rate. We hypothesised that several successive MBs over a short distance wil considerably affect the smolt downstream migration and will have detrimental consequences on the escape rate. The third aim was to determine at a more fine-scale level the behaviour of the smolts at a specific hydropower station that offers two migration routes (an Archimedes screw and a weir) by identifying (a) the diversity of the smolt behavioural tactics and (b) the proportions of the migration routes used. We hypothesised diversified fine-scale searching behaviour of the smolts upstream of the hydropower station, and a low use of the Archimedes screw, based on one previous study that highlighted a poor use of the screw compared to the other available migration routes at the dam (Renardy et al., 2020).

\section{2 | MATERIALS AND METHODS}

\section{1 | Study site}

The Vesdre is a typical medium-sized gravel-bed river, $72 \mathrm{~km}$ long, with its source in the High Fens Natur Park in the Eifel in Belgium near the German border, at an altitude of $626 \mathrm{~m}$, and whose total catchment area extends over $683 \mathrm{~km}^{2}$ into the Meuse river basin (Figure 1a, b). The confluence between the Ourthe and Vesdre rivers is located more than $340 \mathrm{~km}$ from the North Sea. At the study site, the average annual temperature of the Vesdre is $11.1^{\circ} \mathrm{C}$ and water discharge is $10.67 \mathrm{~m}^{3} / \mathrm{s}$. In the whole river, physicochemical parameters and prevailing macro-invertebrate communities are currently indicative of medium-good quality (Public Service of WalloniaAQUABIO). The natural average slope of the Vesdre is $7.8 \%$, but the profile is highly disturbed by the presence of the large reservoir weir at Eupen (126 ha) in the upper part of the river and by $28 \mathrm{MBs}$. The lower part of the Vesdre river corresponds to a mixed grayling and barbel zone (Huet, 1949) with the potential presence of 22 fish species, including some representative of good ecological conditions: the brown trout (Salmo trutta), the European eel (Anguilla anguilla) and the grayling (Thymallus thymallus) (Ovidio et al., 2020). The Atlantic salmon is in a reintroduction phase with a population that is not self-sustainable and involves a restocking programme.

The study site, a river stretch $18.5 \mathrm{~km}$ long, is located in the lower part of the Vesdre and a 0.4-km section of the Ourthe river after the confluence zone (Figure 1c). The study site is divided into five river stretches $\left(S_{1}\right.$ to $\left.S_{5}\right)$, which are, respectively, 2960, 970, 3100, 4740 and $5440 \mathrm{~m}$ long. The river stretches are fragmented by fourteen MBs (Figure 1c). Of the 14 consecutive migration barriers, five of them were equipped with automated radio listening stations (ALSs) and were named from MB1 to MB5, which include four hydropower stations and one weir and the nine others were named intermediate migration barriers (IMB) (Table $1 \&$ Figure 2).

Hydropower station MB1 is located $15.3 \mathrm{~km}$ upstream from the end of the study site. The weir is a concrete structure with an indentation on the left side. On the right bank of the river, an intake channel of $190 \mathrm{~m}$ diverts water towards a vertical Kaplan turbine (Table 1) with a diameter of $1.3 \mathrm{~m}$ and a head of $4 \mathrm{~m}$. The inclined bar rack is equipped with an automatic rack cleaner that collects the debris for evacuation to a flushing channel. The minimum flow section is $360 \mathrm{~m}$ long.

Hydropower station MB2 is located $14.3 \mathrm{~km}$ upstream from the end of the study site. The weir is a concrete structure, and on the left bank of the river an intake channel of $30 \mathrm{~m}$ diverts water towards 

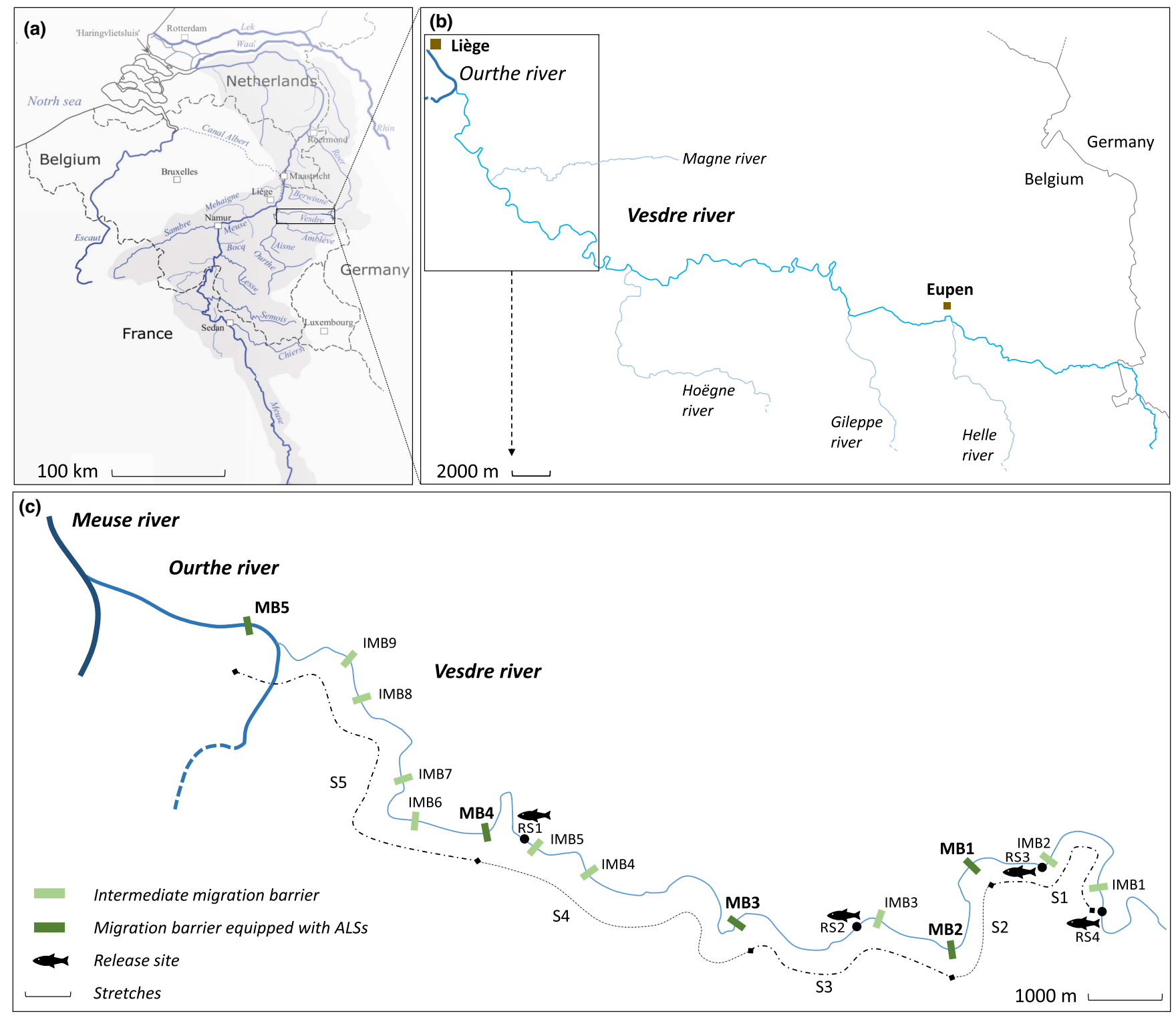

FIGURE 1 Representation of the study area. (a) Overview of the Meuse river basin including the Vesdre river. (b) Overview of the entire Vesdre river. (c) Overview of the Vesdre and Ourthe rivers showing studied stretches and location of MBs and release sites

TABLE 1 Characteristics of the MBs equipped with detection antennas (location in Figure1)

\begin{tabular}{|llllll}
\hline & MB1 & MB2 & MB3 & MB4 & MB5 \\
\hline Drop height $(\mathrm{m})$ & 1.6 & 1.5 & 2.8 & 1.5 & 4 \\
\hline Turbine type & Kaplan & Francis & Kaplan & $\begin{array}{c}\text { Archimedes } \\
\text { screw }\end{array}$ & $/$ \\
Turbine diameter $(\mathrm{m})$ & & & \multicolumn{4}{c}{3.1} & $/$ \\
\hline Turbine activity & 1.3 & - & 1.6 & On & $/$ \\
\hline Rotational speed $(\mathrm{rpm})$ & On & On & Off & On \\
\hline Nominal water discharge $\left(\mathrm{m}^{3} / \mathrm{s}\right)$ & 3 & 8 & 9 & 5 & $/$ \\
\hline Bar rack & $>50^{\text {a }}$ & 200 & $>50^{\text {a }}$ & 25.9 & $/$ \\
\hline Bar spacing $(\mathrm{mm})$ & Yes & Yes & Yes & $/$ & $/$ \\
\hline
\end{tabular}

${ }^{\text {a }}$ Data deduced from the operating characteristics of the turbines a Francis turbine (Table 1) with a head of $2 \mathrm{~m}$. The slightly inclined bar rack is equipped with an automatic rack cleaner that collects the debris and evacuates to a flushing channel. On the right side of the bar rack, an indentation enable to evacuate large debris, and might be used by the downstream-migrating smolts. The minimum flow section is $290 \mathrm{~m}$ long.

Hydropower station MB3 is located $10.9 \mathrm{~km}$ upstream from the end of the study site. The weir is characterised by three spillway 

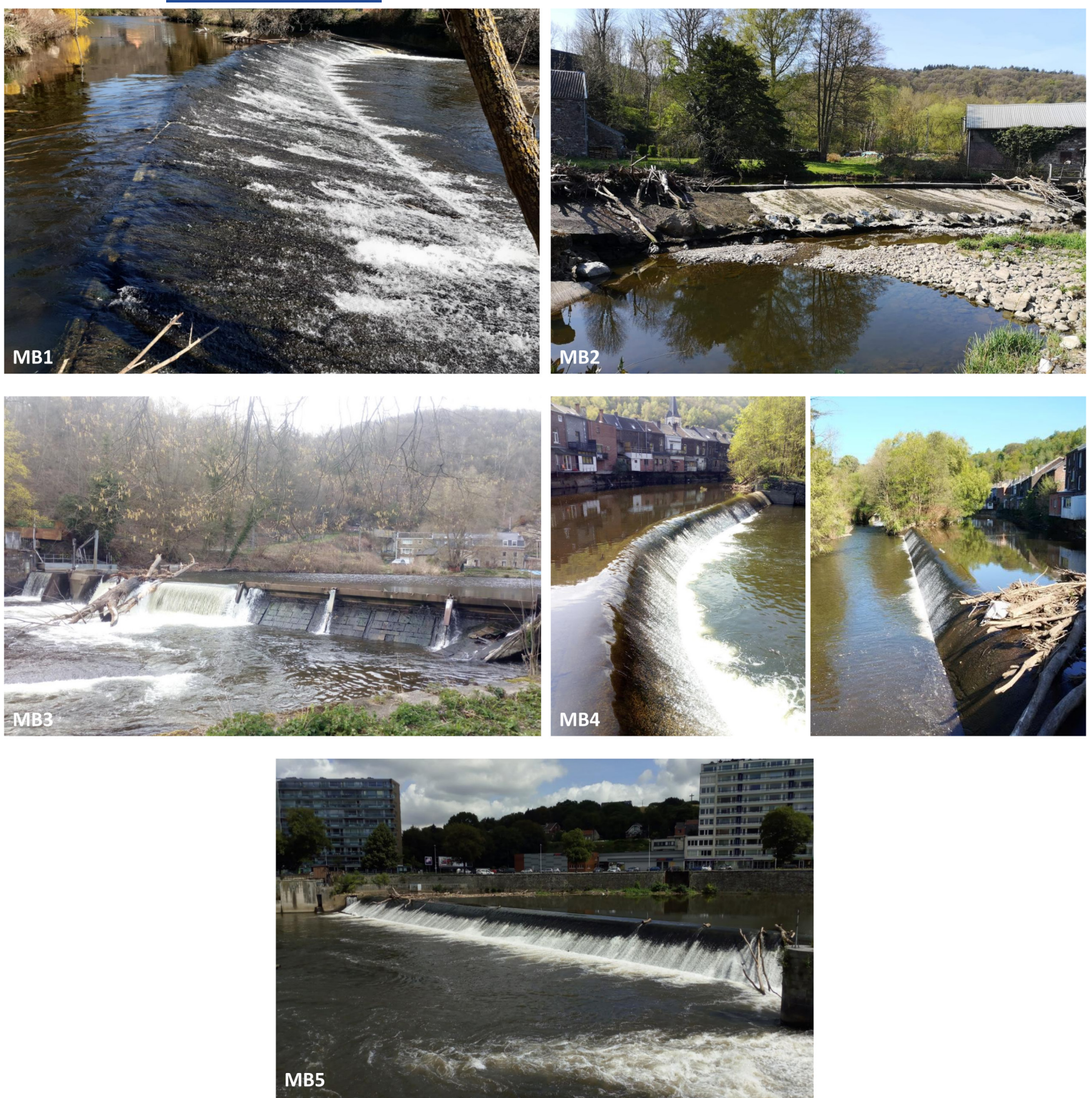

FIGURE 2 Photographic representations of the five MBs equipped with detection antennas

gates and two emptying gates. On the right bank of the river, an intake channel of $230 \mathrm{~m}$ diverts water towards a dual vertical Kaplan turbine (Table 1) with a diameter of $1.6 \mathrm{~m}$ and a head of $4.5 \mathrm{~m}$. A slightly inclined bar rack is equipped with an automatic rack cleaner that collects the debris and evacuates to a flushing channel. The minimum flow section is of $570 \mathrm{~m}$ long.

Hydropower station MB4 is located $5.6 \mathrm{~km}$ upstream of the end of the study site. The weir is characterised by a division into two parts. An Archimedes screw is located on the right bank of the river (Table 1), which has a diameter of $3.1 \mathrm{~m}$ and head of $1.48 \mathrm{~m}$. During the study, the mean turbine rotational speed was $23.8 \mathrm{rpm} \pm 2.99 \mathrm{rpm}$.
Weir MB5 is located in the Ourthe river, $400 \mathrm{~m}$ downstream of the confluence between the Vesdre and the Ourthe rivers. The weir is characterised by two emptying gates on the left side.

The other nine of the 14 consecutive migration barriers were unequipped with $A L S s$ and were considered as intermediate migration barriers (IMB1 to IMB9). IMB1 and IMB2 are hydropower stations. The weir of the IMB1 is characterised by an L-shaped concrete structure, and on the right bank of the river, an intake channel of $500 \mathrm{~m}$ diverts water towards a horizontal Kaplan turbine. A slightly inclined bar rack is equipped with an automatic rack cleaner that collects the debris and evacuates to a flushing channel. The weir of the IMB2 is 
characterised by an L-shaped concrete structure with one emptying gate. On the right bank of the river, an intake channel of $30 \mathrm{~m}$ diverts water towards a vertical Kaplan turbine with a head of $4 \mathrm{~m}$. A slightly inclined bar rack is equipped with an automatic rack cleaner that collects the debris and evacuates to a flushing channel. The IMB7 corresponds to a $75 \mathrm{~m}$ long block ramp weir with a $1.7 \mathrm{~m}$ head. The six other IMBs correspond to concrete-structured overspill weirs, of which the drop height varies between 1.10 to $1.82 \mathrm{~m}$. These IMBs are equipped with one incision and/or one mobile gate.

\section{2 | Smolt tagging and tracking}

We used randomly selected 1-year-old smolts $(n=200)$ from the Erezee Hatchery (Belgium). The hatchery-reared smolts had a mean fork length of $156.3 \mathrm{~mm} \pm 9.27 \mathrm{~mm}$ and a mean body mass of $43.5 \pm 7.99 \mathrm{~g}$ (Table 2). Fork length and body mass varied significantly between the four release events (Kruskal-Wallis (KW) test, both $p<.001)$. Mean fork length and body mass increased with the season progression from $151.2 \mathrm{~mm}$ and $40.1 \mathrm{~g}$ for the first release event to $161.7 \mathrm{~mm}$ and $47.6 \mathrm{~g}$ for the last release event.

Before release events, the smolts were anaesthetised with $0.2 \mathrm{ml} / \mathrm{L}$ of phenoxyethanol. After a $10-\mathrm{mm}$ incision, the smolts were surgically equipped with a radio transmitter in their body cavity (Sigma Eight Inc.; Model TX-PSC-I-8-D; $17 \mathrm{~mm} \times 7 \mathrm{~mm} \times 5.5 \mathrm{~mm}$; mass in air $0.8 \mathrm{~g}$; expected lifetime 20 days). The incision was closed with two stitches using absorbable suture material and disinfected with eosin (Renardy et al., 2020). All tagged smolts were placed for one hour in basins to recover before being released. Water temperature $\left({ }^{\circ} \mathrm{C}\right)$ was recorded every hour during the study using data

TABLE 2 Release strategy of the tagged smolts

\begin{tabular}{|lllll|}
\hline Group & N smolts & $\begin{array}{l}\text { Release } \\
\text { site }\end{array}$ & $\begin{array}{l}\text { Release event } \\
\text { (date) }\end{array}$ & $\begin{array}{l}\text { Release } \\
\text { time }\end{array}$ \\
\hline 1 & 15 & RS 1 & $1(31-03)$ & $14: 29$ \\
& 15 & & $2(08-04)$ & $14: 39$ \\
& 15 & & $3(15-04)$ & $15: 11$ \\
& 15 & & $4(22-04)$ & $15: 50$ \\
\hline 2 & 15 & RS 2 & $1(31-03)$ & $14: 40$ \\
& 15 & & $2(08-04)$ & $14: 25$ \\
& 15 & & $3(15-04)$ & $15: 10$ \\
& 15 & & $4(22-04)$ & $16: 00$ \\
& 10 & RS 3 & $1(31-03)$ & $12: 12$ \\
& 10 & & $2(08-04)$ & $12: 00$ \\
& 10 & & $3(15-04)$ & $12: 10$ \\
\hline 4 & 10 & & $4(22-04)$ & $12: 00$ \\
& 10 & RS 4 & $1(31-03)$ & $12: 12$ \\
& 10 & & $2(08-04)$ & $12: 10$ \\
& 10 & & $3(15-04)$ & $12: 13$ \\
& 10 & & $4(22-04)$ & $12: 13$ \\
\hline
\end{tabular}

loggers (Tidbit Onset) installed close to the hydropower station MB4. Water discharge data $\left(\mathrm{m}^{3} / \mathrm{s}\right)$ were provided by the Wallonia Public Service of Hydrological Studies (SETHY, Belgium), with one measurement every hour and varied from 1.7 to $9.1 \mathrm{~m}^{3} / \mathrm{s}$.

The smolts were released at the four different release locations (RS1-RS4) on four different days in 2020 (31 March, 8 April, 15 April and 22 April). Different release events enabled contrasting environmental conditions. Water temperature varied from $9.8^{\circ} \mathrm{C}$ for the first release event to $13.4^{\circ} \mathrm{C}$ for the last release event. Water discharge decreased from $6 \mathrm{~m}^{3} / \mathrm{s}$ at the first release event to $4.1 \mathrm{~m}^{3} / \mathrm{s}$ at the last release event (Figure 3). The different release sites (RS) are located, respectively, 7, 11.9, 16.7 and $18.9 \mathrm{~km}$ upstream of the end of the study site (RS1 to RS4) and the smolts had to cross 6, 9, 12 and $14 \mathrm{MBs}$, respectively (Figure 1c). Different release sites enabled the assessment of the negative impact of the number of MBs to cross on smolt migration patterns. At RS1 and RS2, $n=15$ fish were released on each occasion whereas at RS3 and RS4, $n=10$ fish were released on each occasion creating a total of 16 release groups (Table 2). For the analysis of the results, the released smolts were grouped in four groups $\left(G_{1}\right.$ to $\left.G_{4}\right)$ based on the release location (RS1 to RS4). The smolts of the same release location were grouped together.

The smolts were tracked passively by nine ALSs linked to Yagi antennas (Sigma Eight Inc., Model Orion; identifiable coded frequency $150 \mathrm{MHz}$ ), which were fixed upstream and/or downstream of the five MBs (MB1 to MB5) (Figure 4). The positioning of the upstream and the downstream ALSs depended on the difficulty in accessing the $\mathrm{MB}$, the availability of an electrical source and also the configuration of the hydropower station and the associated tailrace. The position of the downstream antenna varied between 180 and $570 \mathrm{~m}$ downstream of the MB. For upstream antennas, only the antenna of MB1 was far from the MB, $160 \mathrm{~m}$ upstream of the MB.

The smolts were detected when they approached the ALS at a distance of $\sim 100 \mathrm{~m}$. In addition, receivers with underwater antennas (detection distance: radius of around $3 \mathrm{~m}$ ) were placed upstream and/or downstream in order to analyse the choice of migration routes at two hydropower stations (MB3 \& MB4; Figure 4). Manual tracking was performed, on the release days and the days following, close to both the release sites and the $14 \mathrm{MBs}$ of the study site, in order to confirm the downstream-migration initiation of the smolts as well as to find the smolts that would not be detected at the MBs by the ALSs.

\subsection{Smolt behavioural metrics}

The smolt detections by the ALSs network enabled the definition of several quantitative behavioural metrics useful to describe smolt migration over several MBs:

- Behavioural tactics: expressed behaviour by the smolts upstream of a MB, which includes, notably, the research time and the approached and used migration routes. 


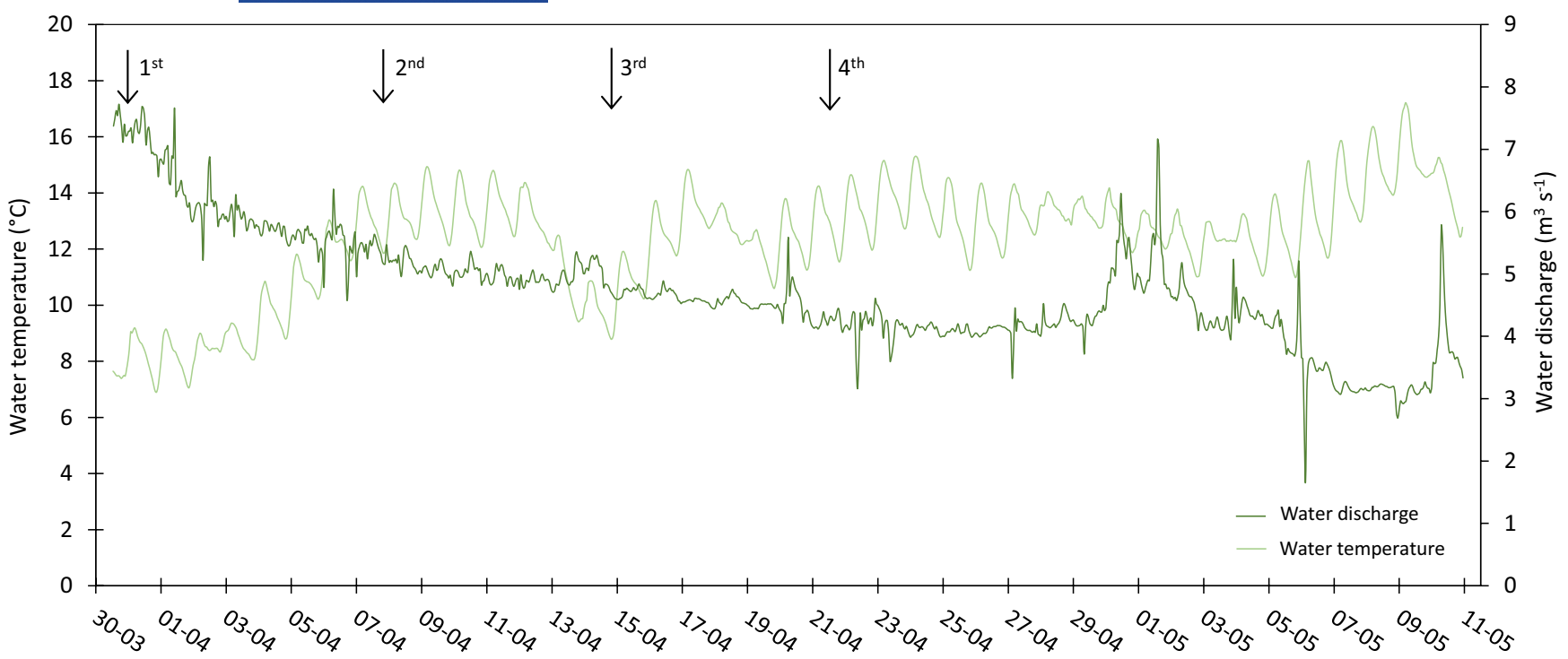

FIGURE 3 Environmental conditions of the Vesdre river during the smolt tracking. The four release events are represented by a black arrow

- Arrival time: median hourly time per $\mathrm{km}$ to reach the first hydropower station, that corresponds to the time between the release time and the first detection at an equipped MB.

- Research time: median hourly time required by the smolts to pass through a MB. It corresponds to the time between the first and last detection upstream of a MB.

- Crossing time: median time between the last detection upstream of a MB and the first detection downstream of the site.

- Crossing speed: median speed $(\mathrm{m} / \mathrm{s})$ between the last detection upstream of a MB and the first detection downstream of the site.

- Crossing delay: median hourly time required to cross a MB, which includes the research and the crossing times.

- Cumulative crossing delay: median sum of crossing delays of each smolt during downstream migration.

- Progression time: median hourly time between the first detection at the first MB and the first detection downstream of weir MB5, which includes the cumulative crossing delay.

- Progression speed: median speed $(\mathrm{m} / \mathrm{s})$ between the first detection at the first MB and the first detection downstream of weir MB5.

- Escape rate: percentage of individual smolts detected downstream of weir MB5 in comparison to the smolts detected by at least one antenna.

\section{4 | Statistical analyses}

Because data violated the assumptions of normality (the ShapiroWilk test, $p<.05)$, non-parametric tests were used. All statistical analyses were performed using the software $\mathrm{R}$ (version 3.4.2).

All the smolts never detected by the automatic tracking system were included in the initial mortality rate. These smolts were not taken into consideration in the analysis of the downstream-migration results. The effect of water discharge and temperature on the initial mortality rate was tested, by using Spearman correlations.

We first performed analyses to respond to the first two objectives and to test the hypothesis on isolated and cumulative impacts of several MBs. Before reaching the first MB equipped with ALSs, the arrival times were identified and compared between the groups $\left(G_{1}\right.$ to $\left.G_{4}\right)$, by using $K W$ and Dunn's tests. To evaluate the specific delays of each MB (MB1 to MB5), research time, crossing time, speed and delay were compared between the hydropower stations by using Kruskal-Wallis (KW) and Dunn's tests. The effects of different environmental factors, such as temperature and water discharge, on all of these behavioural metrics, were assessed by using Spearman correlations. To assess the cumulative impact of successive MBs, the progression speed was compared between the groups $\left(G_{1}\right.$ to $\left.G_{4}\right)$ and progression speed between the stretches $\left(S_{1}\right.$ to $\left.S_{5}\right)$ by using KW and Dunn's tests. The effect of distance travelled and number of MBs on cumulative crossing delay, progression time and speed were tested by using Spearman correlations. Concerning the cumulative mortality rate, correlations between mortality rate during migration and the distance travelled or the number of MBs were tested by using Spearman correlations. The repartition of escaped and dead smolts was compared between the groups by using a Pearson's $\chi^{2}$ test.

Finally, analyses were completed to respond to our last objective on the diversity of fine-scale behaviour and the use of migration route at a MB equipped with an Archimedes screw. The proportion of use of the two migration routes was compared to theoretical proportions by using a Pearson's $\chi^{2}$ test. Research time was compared between the migration routes used by using Mann-Whitney (U) test. The effects of environmental factors on the behavioural metrics were tested, by using $U$ tests for the migration route used 


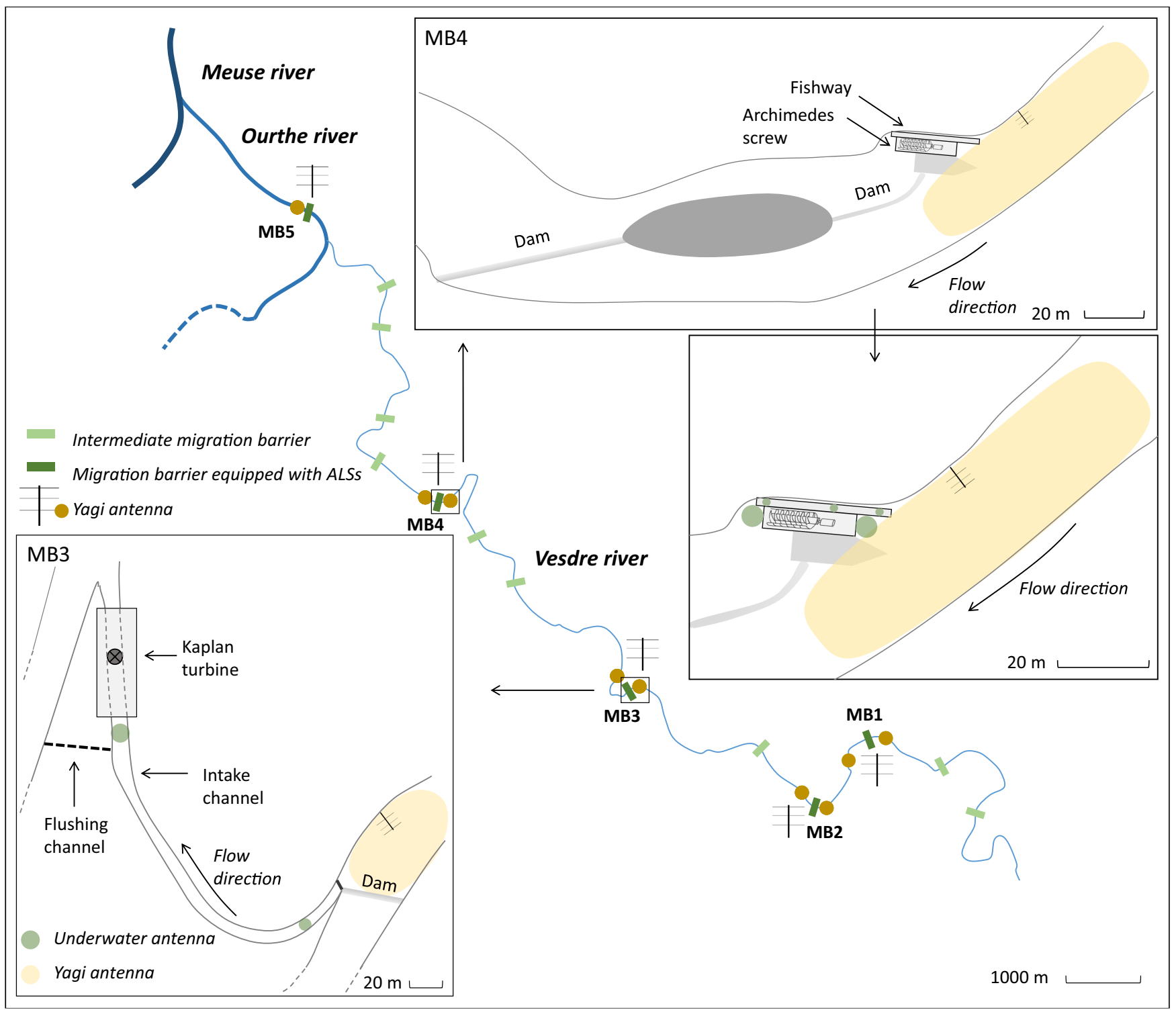

FIGURE 4 Overview of the tracking system on the studied stretches and representation of both Yagi and underwater antennas associated with their detection range at two hydropower stations (MB3 and MB4)

and Spearman correlations for the research time. After using the Archimedes screw, the correlation between the water discharge and the time required to pass through the screw was evaluated by using the Spearman test.

\section{3 | RESULTS}

\section{1 | Initial mortality rate}

Of the 200 released smolts, 50\% started the downstream migration. The other individuals were never detected by the automatic tracking system and corresponded to initial mortality. Water temperature was not significantly related to the initial mortality rate (Spearman correlation, rho $=-0.43, p=.09$ ), but the initial mortality rate tended to be reduced when water temperature increased.

\subsection{Migration patterns according to release site}

The smolts of the $\mathrm{G}_{4}$ were released $18.9 \mathrm{~km}$ upstream of the end of the study site and $45 \%(n=18 / 40)$ started the downstream migration. $\mathrm{N}=17$ smolts were detected at MB1 from twelve hours to more than four days after the initiation of the migration. $\mathrm{N}=14$ were detected at MB2, of which $n=7$ smolts reached the MB3. Afterwards, $n=7$ smolts were recorded at MB4. A total of $n=4$ smolts (one smolt of each release event) were detected downstream of the MB5 from three to eight days after the initiation of the migration (Figure 5a).

The smolts of the $\mathrm{G}_{3}$ were released $16.7 \mathrm{~km}$ upstream of the end of the study site and $60 \%(n=24 / 40)$ started the downstream migration. The $n=24$ smolts were detected at MB1 from three hours to four days after the initiation of the migration. $N=17$ were detected at MB2, of which $n=8$ smolts reached the MB3. Afterwards, $n=7$ smolts were recorded at MB4. A total of $n=6$ smolts 


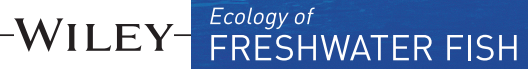

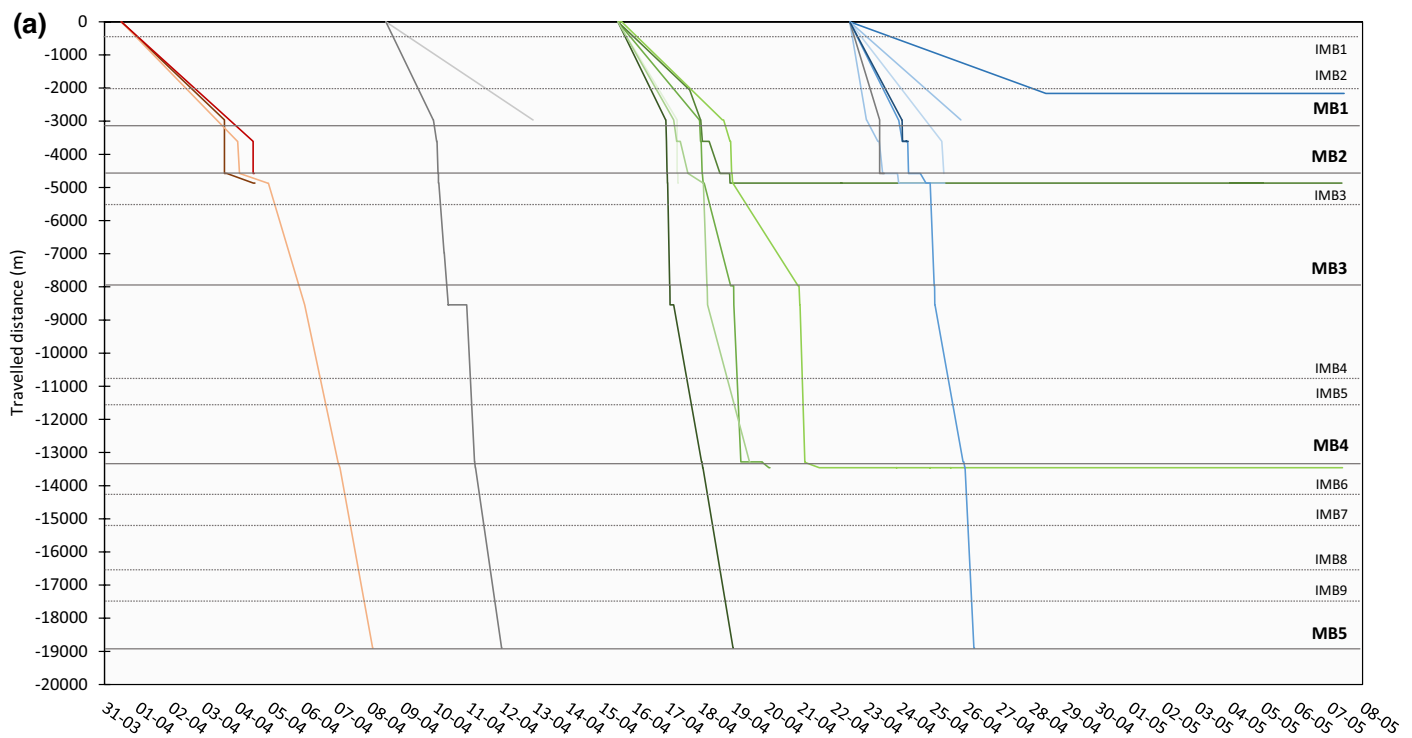

(b)
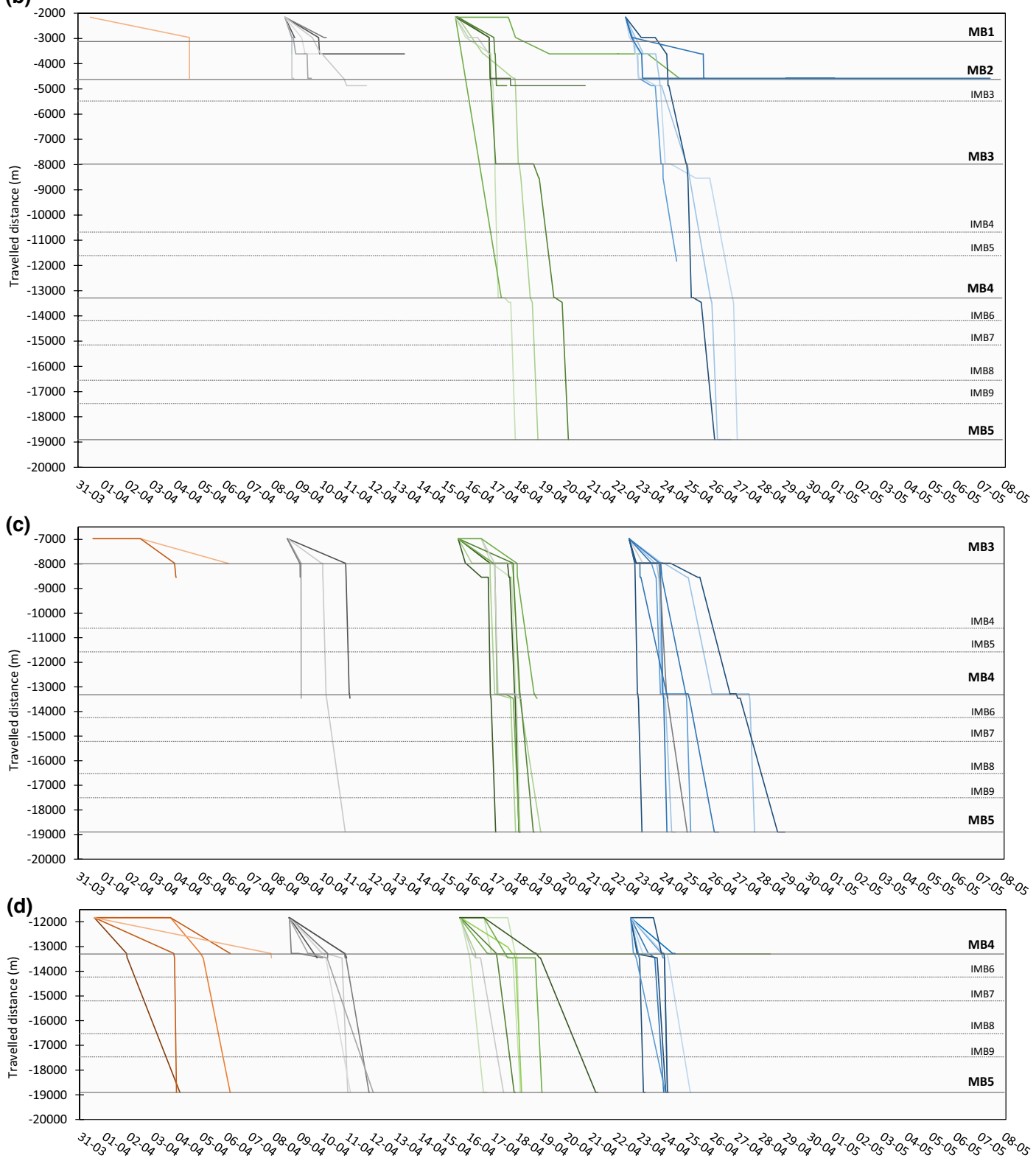
FIGURE 5 Overview of migration patterns of each individual smolt of each group over the entire studied stretch in spring 2020. (a) $\mathrm{G}_{4}$. (b) $G_{3}$. (c) $G_{2}$. (d) $G_{1}$. Each colour represents one release event (1 to 4). MBs equipped with ALSs are represented by solid line and intermediate MBs by dotted line

( $n=3$ smolts of the $3^{\text {rd }}$ release event and $n=3$ of the $4^{\text {th }}$ release event) were detected downstream of the MB5 from two to five days after the initiation of the migration (Figure $5 b$ ).

The smolts of the $\mathrm{G}_{2}$ were released $11.9 \mathrm{~km}$ upstream of the end of the study site and $42 \%(n=25 / 60)$ started the downstream migration. The $n=25$ smolts were detected at MB3 from five hour to more than five days after the initiation of the migration. Afterwards, $n=20$ smolts were detected at MB4. A total of $n=16$ smolts ( $n=1$ smolts of the $2^{\text {nd }}$ release event, $n=7$ of the $3^{\text {rd }}$ release event and $n=8$ of the $4^{\text {th }}$ release event) were detected downstream of the MB5 from one to six days after the initiation of the migration (Figure 5c).

The smolts of the $G_{1}$ were released $7 \mathrm{~km}$ upstream of the end of the study site and $55 \%(n=33 / 60)$ started the downstream migration. The $n=33$ smolts were detected at MB4 from two hours to seven days after the initiation of the migration. A total of $n=22$ smolts $\left(n=3\right.$ smolts of the $1^{\text {st }}$ release event, $n=4$ of the $2^{\text {nd }}$ release event, $n=8$ of the $3^{\text {rd }}$ release event and $n=7$ of the $4^{\text {th }}$ release event) were detected downstream of the MB5 from one to six days after the initiation of the migration (Figure $5 \mathrm{~d}$ ).

\section{3 | Specific delays at isolated hydropower stations}

Once released, the median arrival time to reach the first hydropower station of interest varied from $6.6 \mathrm{~h} / \mathrm{km}$ to $30.1 \mathrm{~h} / \mathrm{km}$ (Figure 6a) and differed significantly between the groups ( $K W$ test, $\chi^{2}=10.9, \mathrm{df}=3$, $p=.01$ ). Arrival time at $\mathrm{G}_{2}$ was significantly higher than at $\mathrm{G}_{3}$ and $\mathrm{G}_{4}$ (Dunn's test, $p<.001$ and $p=.03$, respectively). Despite two intermediate $M B s$ to cross, arrival times at $G_{4}$ did not differ significantly from arrival times of $\mathrm{G}_{3}(\mathrm{U}$ test, $p>$.1). The arrival time was influenced by water temperature at the release time (Spearman's correlation, rho $=-0.43, p<.001$ ), with a reduced arrival time associated with an elevated water temperature.

The median research time required to find a migration route varied between $0.1 \mathrm{~h}$ and $0.7 \mathrm{~h}$ depending on the hydropower station (Figure 6b). Research time differed significantly between the hydropower stations (KW test, $\chi^{2}=23.4, \mathrm{df}=3, p<.001$ ). Research time at MB1 was significantly lower than at the three other hydropower stations (MB2, MB3 and MB4; Dunn's test, $p=.007, p<.001$ and $p=.004$, respectively).

The smolts required a median crossing time between $0.5 \mathrm{~h}$ and $2.4 \mathrm{~h}$ depending on the hydropower station (Figure 6c). The median crossing speed of the smolts varied between 0.06 (MB4), 0.07 (MB1), 0.13 (MB2) and $0.19 \mathrm{~m} / \mathrm{s}$ (MB3) and differed significantly between the hydropower stations ( $\mathrm{KW}$ test, $\chi^{2}=15.7, \mathrm{df}=3, p=.01$ ). Crossing speed at MB3 was significantly higher than at MB4 (Dunn's test, $p<.001)$.
The median crossing delay generated by the hydropower stations varied between 1 and $2.9 \mathrm{~h}$ but did not differ significantly depending on the hydropower stations ( $\mathrm{KW}$ test, $\chi^{2}=0.23$, df $=3, p>.1$; Figure 6d).

Depending on the hydropower station, the associated passage failure varied from $5 \%$ ( $n=2 / 39$ smolts, MB3), $6 \%$ ( $n=4 / 67$, MB4), $12 \%(n=5 / 42$, MB1) to $32 \%(n=10 / 31, M B 2)$.

\subsection{Cumulative delays over multiple migration barriers}

The median progression speed of the smolts fluctuated between 0.05 and $0.1 \mathrm{~m} / \mathrm{s}$ (Table 3 ) and did not differ significantly between the groups ( $\mathrm{KW}$ test, $\chi^{2}=3.4 \mathrm{df}=3, p>.1$ ). The number of MBs did not influence the progression speed (Spearman's correlation, rho $=0.06, p>.1$ ). The smolts migrated with a median migration speed varying between $0.14 \mathrm{~m} / \mathrm{s}$ (range $0.02-0.55$, s3), $0.17 \mathrm{~m} / \mathrm{s}$ (range $0.002-0.70, \mathrm{~s} 2$ ) and $0.20 \mathrm{~m} / \mathrm{s}$ (range 0.04-0.60, S4) but the speed did not differ significantly between the stretches ( $\mathrm{KW}$ test, $\left.\chi^{2}=15.7, \mathrm{df}=3, p>.1\right)$. In the stretch $\mathrm{S}_{5}$, the median smolt migration speed was $0.11 \mathrm{~m} / \mathrm{s}$ (range $0.02-0.76 \mathrm{~m} / \mathrm{s}$ ) to downstream of weir MB5. Migration speed at the stretch $\mathrm{S}_{5}$ was slightly correlated with the number of MBs crossed upstream (Spearman's correlation, rho $=0.25, p=.08$ ).

Once detected at their respective first hydropower station, the median progression time up to weir MB5 varied between 28.5 and $63.9 \mathrm{~h}$ (Table 3), depending on the distance travelled (Spearman's correlation, rho $=0.42, p=.003$ ). The median cumulative crossing delay varied between 2.6 and $32.1 \mathrm{~h}$ and was influenced by the number of MBs (Spearman's correlation, rho $=0.54, p<.001$ ), with an increase in delay when the number of MBs increased.

\subsection{Cumulative mortality and escape rates}

Mortality rate of the migrating smolts, including both in river mortality and passage failure at MBs, reached a total of $52 \%$ $(n=52 / 100)$. Smolt mortality in each river stretch varied between $8 \%\left(n=3 / 37\right.$ smolts, $\left.S_{4}\right), 16 \%\left(n=6 / 37, S_{2}\right), 21 \%\left(n=16 / 63, S_{5}\right)$ and $33 \%\left(n=11 / 31, S_{3}\right)$. Intermediate MBs did not influence the mortality rate in river stretches (Spearman's correlation, rho $=0$, $p=1)$.

Mortality rate varied between the groups, from $33 \%$ $\left(n=11 / 33, G_{1}\right), 36 \%\left(n=9 / 25, G_{2}\right)$ to $76 \%\left(n=19 / 25, G_{3}\right.$ and $n=13 / 17, G_{4}$; Figure 7). Distance travelled and number of MBs were correlated with smolt mortality (Spearman's correlation, both, rho $=1, p<.001$ ), with an increasing mortality associated with an increase in travel distance and number of MBs. The 

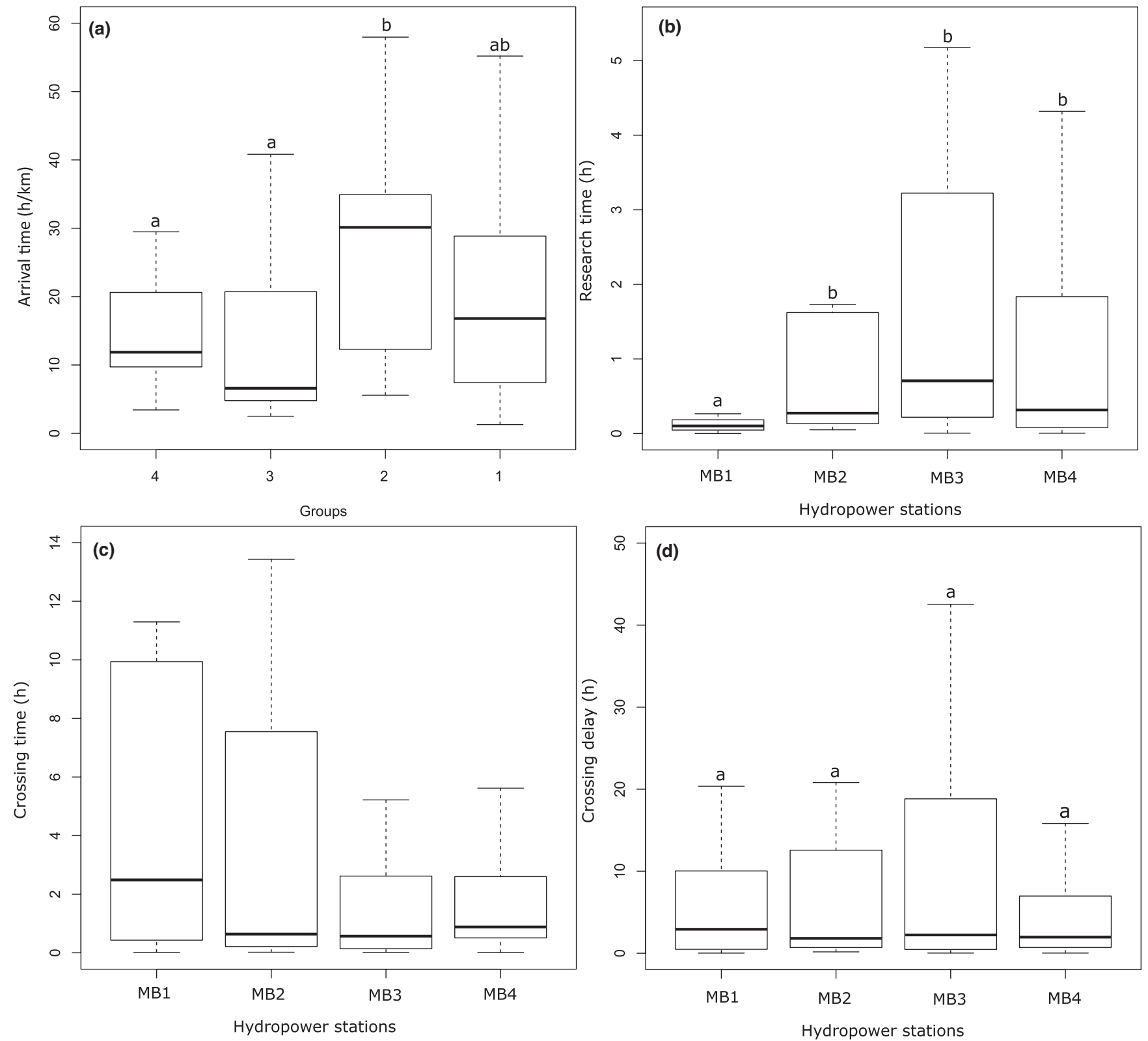

FIGURE 6 Crossing behaviour of smolts at the five MBs. (a) Arrival time required to reach the first MB. (b) Research time required to find a migration route. (c) Crossing time during MB passage. (d) Crossing delay generated by the MB. Quartile 1 and 3: lower and upper box border, median: solid horizontal line, whiskers: smallest and largest value. Values sharing at least one common superscript did not differ at the 0.05 level of significance (KW and Dunn's tests)

repartition of escaped and dead smolts differed significantly between the groups (Pearson's $\chi^{2}, p<.001$ ) and more precisely between downstream $\left(G_{1} \& G_{2}\right)$ and upstream groups $\left(G_{3} \& G_{4}\right.$; Pearson's $\chi^{2}$, all, $\left.p<.001\right)$.

\section{6 | Fine-scale smolt behaviour and migration route used at hydropower station MB4}

Sixty-seven smolts were detected at the MB4 hydropower station and expressed three different behavioural tactics to find a migration route (Figure 8). The first tactic was performed by $n=33$ smolts and consisted of an approach and direct use of the Archimedes screw.
The second was expressed by $n=22$ smolts, who approached and used the weir directly. These first two behavioural tactics were shown by $82 \%$ of the smolts detected upstream of the hydropower station, who approached only one of the two migration routes before crossing the site. The third tactic concerned the remaining $18 \%$ of the smolts ( $n=12$ ), who approached both the weir and the screw before passing the site by the weir.

The Archimedes screw was approached by $67 \%$ of the smolts $(n=45 / 67)$ and the weir by $51 \%(n=34 / 67)$. After a first approach to the Archimedes screw, $71 \%$ of the smolts $(n=30 / 42)$ passed the site by the screw and $29 \%(n=12 / 42)$ used the weir (Figure 8$)$. The ratio between the water turbine and the Vesdre discharge did not influence significantly the migration route used after being detected 
TABLE 3 Downstream-migration behaviour of the smolts over the entire river stretch studied

\begin{tabular}{lllll} 
& $\mathrm{G}_{1}$ & $\mathrm{G}_{2}$ & $\mathrm{G}_{3}$ & $\mathrm{G}_{4}$ \\
\hline Migration barrier number & 6 & 9 & 12 & $12(+2$ not included) \\
$\begin{array}{l}\text { Progression speed (m/s) } \\
\text { median (mean, range) }\end{array}$ & $0.05(0.11,0.02-0.57)$ & $0.10(0.12,0.02-0.42)$ & $0.06(0.07,0.04-0.13)$ & $0.08^{\mathrm{a}}(0.08,0.04-0.09)$ \\
$\begin{array}{l}\text { Progression time (h) } \\
\text { median (range) }\end{array}$ & $28.5(2.7-97.7)$ & $29.1(7.3-146.9)$ & $75.3(49.1-106.5)$ & $52.4^{\mathrm{a}}(49.0-98.1)$ \\
$\begin{array}{l}\text { Cumulative crossing } \\
\text { delay (h) }\end{array}$ & $2.6(0.5-23.4)$ & $14.7(0.9-67.9)$ & $32.1(11.0-56.1)$ & $11.4(3.0-31.9)$ \\
median (range) & & & & \\
\hline
\end{tabular}

${ }^{a}$ Stretch $\mathrm{S}_{1}$ with the two first intermediate MBs is not included in the calculation of progression speed and time.

FIGURE 7 Overview of the smolt mortality of each group $\left(G_{1}\right.$ to $\left.G_{4}\right)$ over the entire studied site including the different river stretches $\left(\mathrm{S}_{2}\right.$ to $\left.\mathrm{S}_{5}\right)$. The $14 \mathrm{MBs}$ are represented by dotted lines

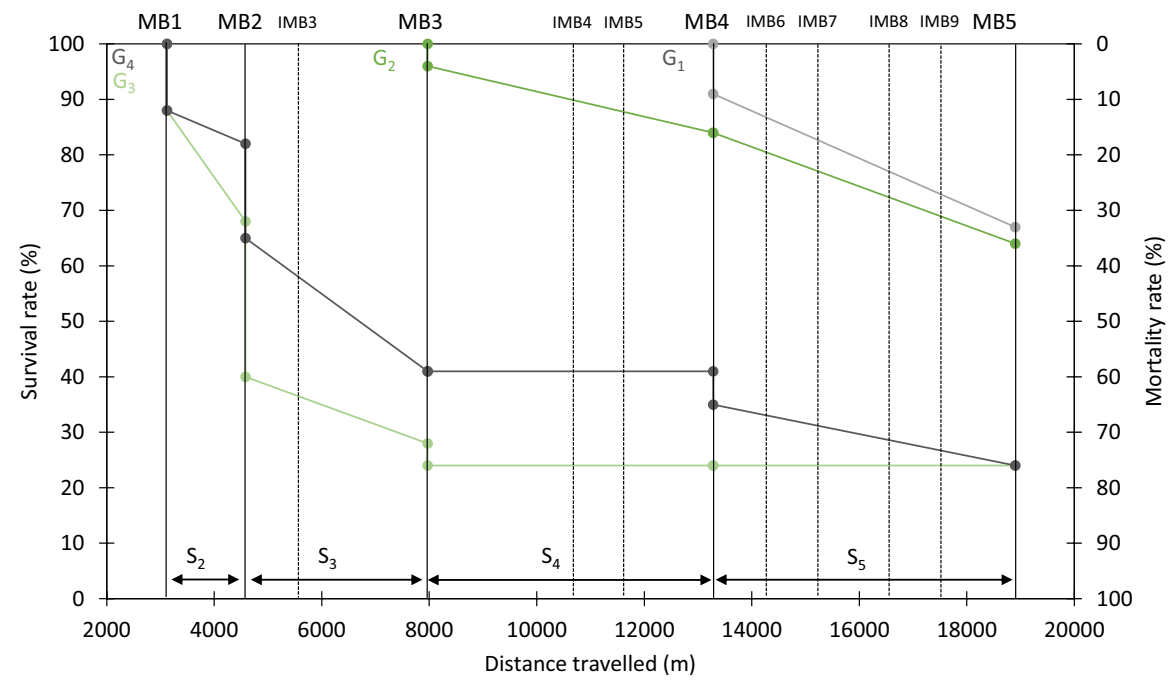

first at the Archimedes screw ( $U$ test, $p=.07$ ), but when the ratio increased the smolts tended towards use of the screw.

The passage rate observed at the site was $94 \%(n=63 / 67)$, and $52 \%(n=33 / 63)$ of the smolts used the weir and $48 \%(n=30 / 63)$ the Archimedes screw (Pearson's $\chi^{2}, p>$.1). Of the 33 smolts that used the weir, $24 \%$ ( $n=8$ ) were detected downstream of the Archimedes screw, suggesting a passage through the right part of the dam (Figure 8). The migration routes used were not influenced by water discharge or the ratio between the water-turbined and the Vesdre discharge ( $U$ test, $p>.1$ ).

The median research time required to find a migration route was $19 \mathrm{~min}$ and did not differ significantly depending on the migration route used ( $U$ test, $p>$.1). The turbine discharge had an effect on research time before using the Archimedes screw as the migration route (Spearman's correlation, rho $=-0.55, p=.002$ ), with a faster crossing when rotational speed increased. The median time to pass through the Archimedes screw was $1 \mathrm{~min}$ (range 1-29 min) and was correlated with the turbine discharge (Spearman's correlation, rho $=-0.84$, $p<.001)$ and with shorter time when turbine discharge increased.

\section{DISCUSSION}

The innovative character of this study was the behavioural tracking of Atlantic salmon smolts over a short and highly impacted gravel-bed river stretch fragmented by six hydropower stations and eight weirs. The hydropower stations were of different typology and equipped with Francis, Kaplan or Archimedes screw turbines. Our experimental telemetry device enabled identification of the smolt behaviour upstream of the different MBs and comparison of the specific impact of isolated hydropower stations and associated turbines. This experimental approach enabled to highlight the cumulative negative effects, in terms of delays and mortalities that the successive MBs caused at the beginning of the downstream migration of the smolts. We have tried to track smolts under variable environmental conditions, but the variability of the conditions obtained in 2020 do not represent a complete vision of what would have happened during other smolt migration seasons in the Vesdre river, especially under more extreme environmental conditions. However, environmental conditions had no statistical effect on the smolt migratory behaviour and the survival rate.

Of the 200 released smolts, $50 \%$ were never detected by the tracking system. A potential negative impact of the tagging procedure on smolt mortality is unlikely as the ratio between weights of transmitter and smolt was less than $2.5 \%$ for $93 \%$ of the smolts, and none was affected by the surgery during the recovery phase before release events. Tagging methodology was identical to those of previous studies carried out using mobile tracking on Atlantic salmon smolts or trout (Ovidio et al., 2007; Renardy et al., 2020) with an absence of mortality after tagging. Tag dysfunction (stopping or 


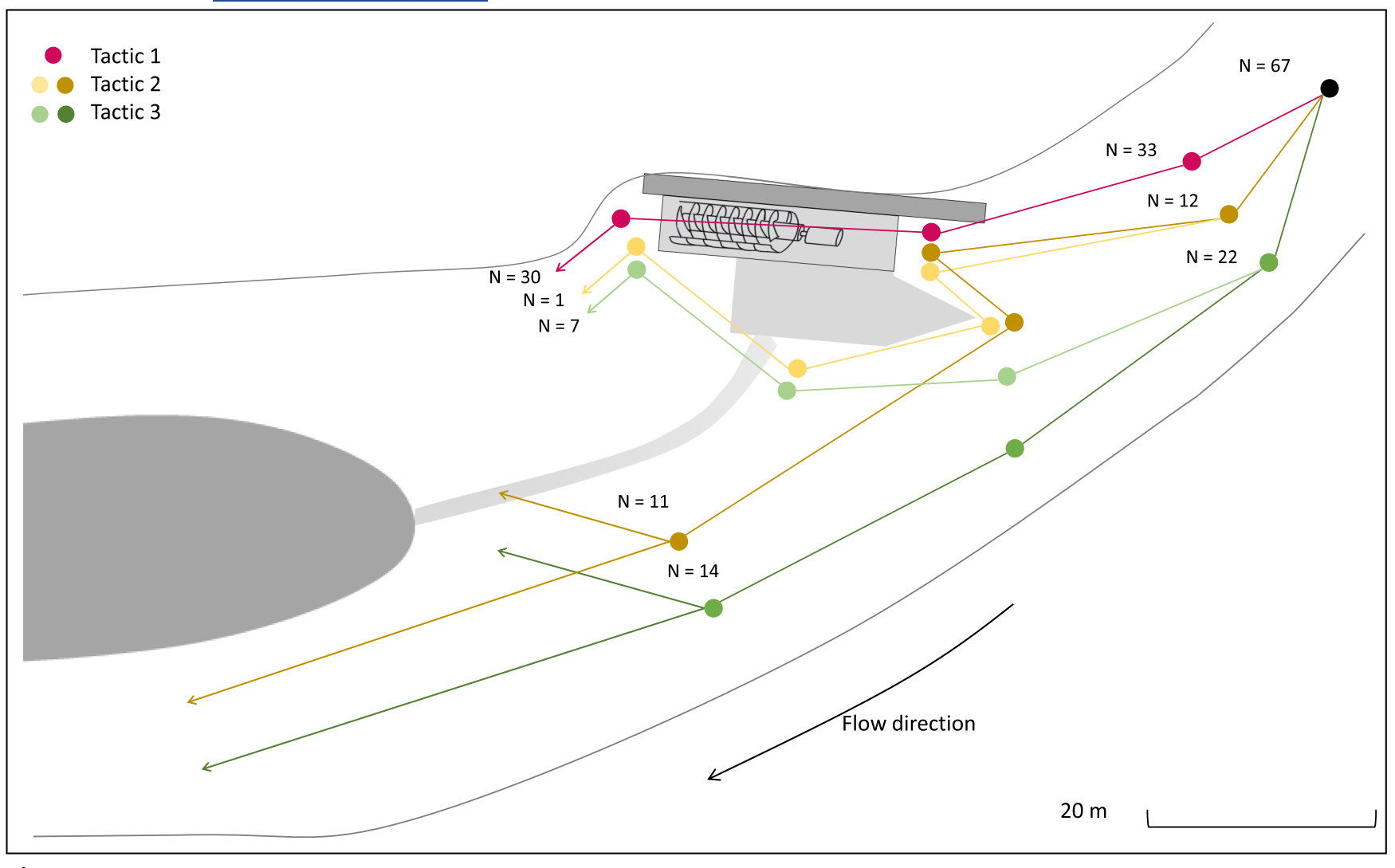

FIGURE 8 Illustration of the different behavioural tactics shown by the smolts at the hydropower station MB4

drift in the emitted frequency) cannot be excluded, whilst usually not affecting more than 1-2\% of tags in our different projects. Based on the results of previous studies on smolt downstream migration, the negative effect of the use of hatchery-reared smolts should not be significant on the course of downstream migration. Indeed, the majority of the smolts, originating from the same hatchery, initiated the migration rapidly and over long distances (Ovidio et al., 2021; Renardy et al., 2020, 2021).

Once released into the river the initiation of smolt downstream migration is correlated with several environmental releasing factors, such as temperature, water discharge and turbidity (McCormick et al., 1998). Karppinen et al. (2014) observed that the high sensitivity towards environmental releasing factors remains in hatcheryreared smolts. In this study, an elevated water temperature at the release event favoured a faster initiation of migration and a reduced arrival time at the first MB. On the contrary, suboptimal environmental conditions, such as slack water and low temperature, sometimes below $10^{\circ} \mathrm{C}$ (Teichert et al., 2020) has engendered a weaker instinct to migrate and led to an increased risk of predation. Timing of release of hatchery smolts is a critical point that strongly influences their survival (Karppinen et al., 2014). Predation may be the main natural cause of mortality during migration (Furey et al., 2021; Thorstad et al., 2012). The presence of several cormorant colonies along the Vesdre river may explain the elevated initial mortality rate of the smolts before the initiation of downstream migration, especially for the two first release events. This hypothesis is reinforced by the loss of radio signals during manual tracking in the days after release. Cormorants, avian predators, are a significant threat to smolts (Brevé et al., 2014; Koed et al., 2006), especially for those hatchery-reared (Reitan et al., 1987).

At the MBs equipped with ALSs, median research time required to find a migration route varied between 6 and $42 \mathrm{~min}$. The small-sized hydropower stations usually have one or two migration routes, most of which include open spillway gates or an overspill weir. The gates are considered to be safe migration routes that may favour a safe and quick passage through the MBs. Newton et al. (2019) highlighted similar research times between 2 and 32 min at overspill weirs. In the literature, the median required time to cross a hydropower station was reported as $0.5 \mathrm{~h}$ by Havn et al. (2020, Francis turbines), $1 \mathrm{~h}$ by Renardy et al. (2020, Kaplan turbines) and from 0.2 to $0.9 \mathrm{~h}$ by Tomanova et al. (2018) in small and medium-sized rivers. Ovidio et al. (2017, Francis turbines) reported a research time of less than $1 \mathrm{~h}$ for the major proportion (70\%) of the smolts. In large-sized rivers, research time varied between $0.4 \mathrm{~h}$ (Larinier et al., 2020) and $4.7 \mathrm{~h}$ (Renardy et al., 2021) at hydropower stations equipped with Kaplan turbines. In our study, after choosing a migration route, the required median crossing time varied between $0.5 \mathrm{~h}$ and $2.4 \mathrm{~h}$. The crossing speed was higher after passage over spillway gates than through Francis turbines or Archimedes screws. Passage through turbines may disorient the smolts, as observed by Coutant and Whitney (2000) and slow them down.

The median crossing delay generated by the isolated MBs varied between $1 \mathrm{~h}$ and $2.9 \mathrm{~h}$. Concerning the IMBs, the six overspill 
weirs and the block ramp encountered by the smolts did not have a significant impact on downstream migration. However, the two first IMBs may have slightly delayed the smolts in their migration progression, before arriving at MB1, probably due to the presence of a hydropower station with a running turbine. The cumulative impact of the successive MBs in the Vesdre river was considerable and reached $2.6 \mathrm{~h}\left(\mathrm{G}_{1}, 5.6 \mathrm{~km}\right), 11.4 \mathrm{~h}\left(\mathrm{G}_{4}, 15.3 \mathrm{~km}\right), 14.7 \mathrm{~h}\left(\mathrm{G}_{2}, 10.9 \mathrm{~km}\right)$ and $32.1 \mathrm{~h}\left(\mathrm{G}_{3}, 15.3 \mathrm{~km}\right)$. This may be a major problem, as the smolts are just at the beginning of their downstream migration in the upper Vesdre river. Smolts need to migrate during a physiological window, a narrow period of time during that environmental conditions and smolt fitness are optimal for downstream migration and entering into the sea (McCormick et al., 1998). Delays during downstream migration may cause a mismatch between migration timing and the physiological window that prevents the smolts reaching the sea in time (Marschall et al., 2011). The more MBs the smolts had to pass through, the greater the cumulative crossing delay and, therefore, the progression time, which varied from $28.5 \mathrm{~h}$ to $63.9 \mathrm{~h}$, depending on the distance travelled.

Median progression speed during downstream migration varied from $0.05 \mathrm{~m} / \mathrm{s}\left(\mathrm{G}_{1}, 6 \mathrm{MBs}\right), 0.06 \mathrm{~m} / \mathrm{s}\left(\mathrm{G}_{3}, 12 \mathrm{MBs}\right), 0.08 \mathrm{~m} / \mathrm{s}\left(\mathrm{G}_{4}\right.$, $12 \mathrm{MBs})$ to $0.1 \mathrm{~m} / \mathrm{s}\left(\mathrm{G}_{2}, 9 \mathrm{MBs}\right)$. Probably due to the intensity of fragmentation, the progression speed in our study was in the lower range of migration speeds listed in the literature. Median progression speed in impacted rivers varied between $0.04 \mathrm{~m} / \mathrm{s}$ (Renardy et al., 2021, 2 MBs), 0.12 m/s (Newton et al., 2019; 7 MBs) and 0.26 m/s (Renardy et al., 2020, 3 MBs). Brevé et al. (2014) highlighted an average migration speed of $0.2 \mathrm{~m} / \mathrm{s}$ in a river section including five MBs. Aarestrup et al. (2002) obtained a high variation of progression speeds in one unimpounded river, from $0.01 \mathrm{~m} / \mathrm{s}$ to less than $0.23 \mathrm{~m} / \mathrm{s}$, and which varied on average between $0.06 \mathrm{~m} / \mathrm{s}$ (Lothian et al., 2018), $0.38 \mathrm{~m} / \mathrm{s}$ (Brevé et al., 2014) and $0.61 \mathrm{~m} / \mathrm{s}$ (Urke et al., 2013). Despite the difference in the number of MBs to cross between groups (6 to $12 \mathrm{MBs}$ ), progression speed was similar between the release sites. It could be assumed that with gained experience of passing through the MBs, smolts might migrate more rapidly, in order to compensate for delays caused by hydropower stations. Assuming that the downstream progression was stable over time, smolts might reach the North Sea after 59 to 72 days of downstream migration.

At the hydropower station MB4, equipped with an Archimedes screw, three different behavioural tactics to find a migration route were expressed by the smolts. The attractiveness of fish-friendly turbines is a key point in downstream-migration studies as, even if they do not cause injuries or mortality, it is important to assess whether the fish approach and use these turbines with a minimal passage delay. Amongst the smolts who passed the site, $52 \%$ used the weir and $48 \%$ the screw. Of the detected smolts, $82 \%$ passed the site by the first approached migration route. Havn et al. (2017) observed the same tendency in passage rate with the use of a screw of $43 \%$ at a site offering six migration routes. On the other hand, Renardy et al. (2020) and Moore et al. (2018) highlighted low Archimedes screw use of $11.8 \%$ and $8.1 \%$, respectively. At the hydropower station MB4, the turbined water discharge induced the redirection of the main watercourse towards the Archimedes screw and did not allow a sufficient water level over the weir to attract the smolts. However, $29 \%$ of the smolts, who approached the Archimedes screw, rejected the screw and passed by the overspill weir. Despite a very low water level over the weir, this route was quite attractive in contrast to reported observations in the literature in low flow conditions (Williams et al., 2012). Renardy et al. (2020) suggested a possible repulsion by the noise and vibration associated with the operating characteristics of the Archimedes screw that may decrease the attractiveness for smolts.

The passage failure rates of the four hydropower stations studied were 5\% (MB3, no running turbine), 6\% (MB4, Archimedes screw), 12\% (MB1, Kaplan turbine) and 35\% (MB2, Francis turbine). Weirs and spillway gates represent, in general, safe alternative migration routes for smolts (Duncan et al., 2018), which may explain the greater passage success at hydropower station MB3, given the turbine shutdown. The high passage success at hydropower station MB4 was probably favoured by the presence of a fish-friendly turbine developed to ensure safe passage for fish (Cefas, 2012). In our study, only one smolt that used an Archimedes screw was not recorded by the downstream antenna. This is in accordance with Brackley et al. (2018), who highlighted very low mortalities following direct injection into such a turbine. However, Pauwels et al. (2020) observed up to $37 \%$ of mortality for large cyprinids. Mortalities induced by Kaplan turbines vary from 0\% (Vikström et al., 2020) to 20\% (Larinier \& Travade, 2002) but may sometimes reach more elevated rates as observed by Kärgenberg et al. (2020) with a mortality rate of around $36 \%$. At hydropower station MB1, equipped with a Kaplan turbine, the associated passage failure of $12 \%$ was within the theoretical mortality range. At hydropower station MB2, during the main part of the study the only available migration route was the Francis turbine, which induced a mortality of $32 \%$. This is in the 5$90 \%$ range proposed by Larinier (2008) depending on the properties of the turbine and the operating characteristics.

In the different river stretches, mortality per $\mathrm{km}$ varied between $1.7 \%\left(\mathrm{~S}_{4}\right.$, total mortality $\left.=8 \%\right), 3.7 \%\left(\mathrm{~S}_{5}\right.$, total mortality $\left.=21 \%\right)$, $10.7 \%\left(\mathrm{~S}_{3}\right.$, total mortality $\left.=33 \%\right)$ and $16.5 \%\left(\mathrm{~S}_{2}\right.$, total mortality $=16 \%$ ), which was higher than the rates reported in the literature. Loss per $\mathrm{km}$ in control stretches without MBs varied between $0.5 \%$, 1.6\% (Havn et al., 2020, 5.8 km) and 2.5\% (Havn et al., 2017, 3 km). In our study, stretches $\mathrm{S}_{3}, \mathrm{~S}_{4}$ and $\mathrm{S}_{5}$ were fragmented by one or more intermediate MBs, which emphasised river mortality. After passage through classical turbines (Mueller et al., 2020) and probably even through fish-friendly turbines, delayed mortalities may occur in river stretches. Based in these suggestions, passage through Francis turbines may have had an effect on postponed mortality in stretch $\mathrm{S}_{3}$. Furthermore, impoundments cause slack water and provide an ideal habitat for avian and piscivorous predators (Thorstad et al., 2012); this especially the case for stretches $S_{2}$ and $S_{3}$, where cormorant colonies were present. The global mortality rate of migrating smolts reached 52\% ( $n=52 / 100)$ and varied between the release sites, from $33 \%\left(G_{1}\right), 36 \%\left(G_{2}\right)$ to $76 \%\left(G_{3}\right.$ and $\left.G_{4}\right)$. Mortality rate tended to increase with the increase in number of MBs and associated distance 
travelled. The mortality rate per $\mathrm{km}$ varied from $3 \%\left(\mathrm{G}_{2}, 10.9 \mathrm{~km}\right), 4 \%$ $\left(G_{4}, 15.3 \mathrm{~km}\right), 4.5 \%\left(\mathrm{G}_{3}, 15.3 \mathrm{~km}\right)$ to $4.7 \%\left(\mathrm{G}_{1}, 5.6 \mathrm{~km}\right) . \mathrm{G}_{1}$ presented the highest mortality rate per km despite the fewest number of MBs to cross. In the literature, the reported loss per $\mathrm{km}$ varied from $0.1 \%$ (Newton et al., 2019, $50 \mathrm{~km}$ ), 0.4\% (Brevé et al., 2014, $110 \mathrm{~km}$ ) to $0.8 \%$ (Huusko et al., 2018, $104 \mathrm{~km}$ ) in impacted rivers with 7, 5 and 5 MBs to cross, respectively. Newton et al. (2019) obtained no smolt loss in an unimpacted river of $58 \mathrm{~km}$, and Thorstad et al. (2012) reported a mortality rate of between $0.3 \%$ and $7 \%$ per $\mathrm{km}$.

The escape rate depending on the release site reached $67 \%\left(\mathrm{G}_{1}\right.$, $5.6 \mathrm{~km}), 64 \%\left(\mathrm{G}_{2}, 10.9 \mathrm{~km}\right)$ and $24 \%\left(\mathrm{G}_{3}\right.$ and $\left.\mathrm{G}_{4}, 15.3 \mathrm{~km}\right)$. Newton et al. (2019) highlighted an escape rate of $18 \%$ in an impacted river of more than $100 \mathrm{~km}$ length impounded by $7 \mathrm{MBs}$. In unimpounded rivers, rates varied between 59\% (Lothian et al., 2018, >45 km) and 78\% (Urke et al., 2013, $14 \mathrm{~km}$ ) depending on the distance travelled. Renardy et al. (2021) reported an escape rate of migrating smolts to the Dutch part of the Meuse river of only $9 \%$ after release downstream of weir MB5 (28 km upstream). Brevé et al. (2014) quantified a seaward escape rate of around 3\% after release in the Roer tributary of the Dutch Meuse river ( $>230 \mathrm{~km}$ ). In some situations, a single hydropower station associated with a navigation canal in the Meuse river may impede the smolt migration of its own (Renardy et al., 2021).

The radio-tracking of individual smolts over a short and highly fragmented gravel-bed river stretch, just at the beginning of their migration process, enabled to validate our different work hypotheses. We demonstrated that isolated hydropower stations caused significant migration delays, but not different from one type of barrier to another despite the difference in typology and/or turbine design. The individual behavioural tactics expressed by the smolts to cross the MB4 were variable, and the Archimedes' screw was not the preferred migration route used, and was repellent for some smolts. Finally, the cumulative crossing delays were detrimental and increased with the number of MBs to cross. These significant delays and mortalities generated over a short stretch of migration may lead to a significantly low seaward escape rate. These problems observed in a tributary are added to those encountered in the main course of the Meuse river further downstream (Renardy et al., 2021). The reintroduction success of the Atlantic salmon in the Meuse basin, must pass by the re-establishment of self-sustaining populations in the future. This is imperatively conditioned by the challenge of a better success of smolt downstream migration from the tributaries to the sea, to expect further quantitative returns of spawning adults. Passage of hydropower stations equipped with classical or fishfriendly turbines should be as fast and secure as possible to reach a good escapement rate to the sea.

\section{ACKNOWLEDGEMENTS}

Financial support for this study was provided by the Public Service of Wallonia, DDRCB - DCENN. Séverine Renardy received a Ph.D. research grant from FNRS-FRIA (Fonds pour la Formation à la Recherche dans l'Industrie et dans l'Agriculture) for a project on the smolt downstream migration. We thank Niels Duchesne for authorising access to the hydropower station equipped with the Archimedes screw during the study and the SPW-SETHY for the water discharge data. We thank the team of the CoSMos hatchery of Erezée for the acquisition of Atlantic salmon smolts.

\section{CONFLICT OF INTEREST}

The authors declare no conflict of interest.

\section{AUTHORS' CONTRIBUTION}

Renardy and M. Ovidio: Wrote the paper. D. Sonny, M. Ovidio, J. P. Benitez, D. Colson and D. Goffaux: Conceived and designed the investigation. S. Renardy, J. P. Benitez, A. Dierckx, M. Ovidio, D. Colson and J. Sabbe. A. Rabouan, D. Sonny: Performed field and/ or laboratory work. Renardy and J. P. Benitez: Analysed the data. D. Sonny and M. Ovidio: Contributed materials, reagents, and/or analysis tools. Paper proofreading: J. P. Benitez, B. Nzau Matondo, D. Colson, D. Goffaux, D. Sonny and O. Detrait. Research project funding: O. Detrait.

\section{DATA AVAILABILITY STATEMENT}

The data that support the findings of this study are available from the corresponding author upon reasonable request.

\section{ORCID}

Séverine Renardy (D) https://orcid.org/0000-0002-0575-1714 Jean-Philippe Benitez (D) https://orcid.org/0000-0002-5643-070X Billy Nzau Matondo (iD) https://orcid.org/0000-0002-7098-9972

Michaël Ovidio (D) https://orcid.org/0000-0002-0136-5840

\section{REFERENCES}

Aarestrup, K., Nielsen, C., \& Koed, A. (2002). Net ground speed of downstream migrating radio-tagged Atlantic salmon (Salmo salar L.) and brown trout (Salmo trutta L.) smolts in relation to environmental factors. In E. B. Thorstad, I. A. Fleming, \& T. F. Næsje, (Eds.), Aquatic Telemetry (pp. 95-102). Springer. https://doi. org/10.1007/978-94-017-0771-8_11

Brackley, R., Lucas, M. C., Thomas, R., Adams, C. E., \& Bean, C. W. (2018). Comparison of damage to live v. euthanized Atlantic salmon Salmo salar smolts from passage through an Archimedean screw turbine. Journal of Fish Biology, 92(5), 1635-1644. https://doi.org/10.1111/ jfb.13596

Brevé, N., Vis, H., Spierts, I., de Laak, G., Moquette, F., \& Breukelaar, A. (2014). Exorbitant mortality of hatchery-reared Atlantic salmon smolts Salmo salar L., in the Meuse river system in the Netherlands. Journal of Coastal Conservation, 18(2), 97-109. https://doi. org/10.1007/s11852-013-0237-4

Cefas, A. (2012). Assessment of Damage to Smolts Caused by Archimedes Screw Hydropower Turbines. T. R: I. Potter, P. Davison and A. Moore, Lowestoft.

Coutant, C. C., \& Whitney, R. R. (2000). Fish quipped in relation to passage through hydropower turbines: a review. Transactions of the American Fisheries Society, 129(2), 351-380. https://doi. org/10.1577/1548-8659(2000)129<0351:FBIRTP>2.0.CO;2

Duncan, J. P., Deng, Z. D., Arnold, J. L., Fu, T., Trumbo, B. A., Carlson, T. J., \& Zhou, D. (2018). Physical and ecological evaluation of a fish-friendly surface spillway. Ecological Engineering, 110, 107-116. https://doi.org/10.1016/j.ecoleng.2017.10.012

Fjeldstad, H.-P., Pulg, U., \& Forseth, T. (2018). Safe two-way migration for salmonids and eel past hydropower structures in Europe: $A$ 
review and recommendations for best-practice solutions. Marine and Freshwater Research, 69(12), 1834. https://doi.org/10.1071/ MF18120

Fullerton, A. H., Burnett, K. M., Steel, E. A., Flitcroft, R. L., Pess, G. R., Feist, B. E., Torgersen, C. E., Miller, D. J., \& Sanderson, B. L. (2010). Hydrological connectivity for riverine fish: Measurement challenges and research opportunities. Freshwater Biology, 55(11), 2215-2237. https://doi.org/10.1111/j.1365-2427.2010.02448.x

Furey, N. B., Martins, E. G., \& Hinch, S. G. (2021). Migratory salmon smolts exhibit consistent interannual depensatory predator swamping: Effects on telemetry-based survival estimates. Ecology of Freshwater Fish, 30(1), 18-30. https://doi.org/10.1111/ eff.12556

Havn, T. B., Sæther, S. A., Thorstad, E. B., Teichert, M. A. K., Heermann, L., Diserud, O. H., Borcherding, J., Tambets, M., \& Økland, F. (2017). Downstream migration of Atlantic salmon smolts past a low head hydropower station quipped with Archimedes screw and Francis turbines. Ecological Engineering, 105, 262-275. https://doi. org/10.1016/j.ecoleng.2017.04.043

Havn, T. B., Thorstad, E. B., Borcherding, J., Heermann, L., Teichert, M. A. K., Ingendahl, D., Tambets, M., Sæther, S. A., \& Økland, F. (2020). Impacts of a weir and power station on downstream migrating Atlantic salmon smolts in a German river. River Research and Applications, 36(5), 784-796. https://doi.org/10.1002/rra.3590

Hogan, T. W., Cada, G. F., \& Amaral, S. V. (2014). The status of environmentally enhanced hydropower turbines. Fisheries, 39(4), 164-172. https://doi.org/10.1080/03632415.2014.897195

Holbrook, C. M., Kinnison, M. T., \& Zydlewski, J. (2011). Survival of migrating Atlantic Salmon Smolts through the Penobscot River, Maine: A prerestoration assessment. Transactions of the American Fisheries Society, 140(5), 1255-1268. https://doi.org/10.1080/00028 487.2011.618356

Huet, M. (1949). Aperçu des relations entre la pente et les populations piscicoles des eaux courantes. Schweizerische Zeitschrift Für Hydrologie, 11(3-4), 332-351.

Huusko, R., Hyvärinen, P., Jaukkuri, M., Mäki-Petäys, A., Orell, P., \& Erkinaro, J. (2018). Survival and migration speed of radio-tagged Atlantic salmon (Salmo salar) smolts in two large rivers: One without and one with dams. Canadian Journal of Fisheries and Aquatic Sciences, 75(8), 1177-1184. https://doi.org/10.1139/cjfas -2017-0134

Kärgenberg, E., Thorstad, E. B., Järvekülg, R., Sandlund, O. T., Saadre, E., $\varnothing$ kland, F., Thalfeldt, M., \& Tambets, M. (2020). Behaviour and mortality of downstream migrating Atlantic salmon smolts at a small power station with multiple migration routes. Fisheries Management and Ecology, 27(1), 32-40. https://doi.org/10.1111/fme.12382

Karppinen, P., Jounela, P., Huusko, R., \& Erkinaro, J. (2014). Effects of release timing on migration behaviour and survival of hatchery-reared Atlantic salmon smolts in a regulated river. Ecology of Freshwater Fish, 23(3), 438-452. https://doi.org/10.1111/eff.12097

Katopodis, C., \& Williams, J. G. (2012). The development of fish passage research in a historical context. Ecological Engineering, 48, 8-18. https://doi.org/10.1016/j.ecoleng.2011.07.004

Koed, A., Baktoft, H., \& Bak, B. D. (2006). Causes of mortality of Atlantic salmon (Salmo salar) and brown trout (Salmo trutta) smolts in a restored river and its estuary. River Research and Applications, 22(1), 69-78. https://doi.org/10.1002/rra.894

Koed, A., Jepsen, N., Aarestrup, K., \& Nielsen, C. (2002). Initial mortality of radio-tagged Atlantic salmon (Salmo salar L.) smolts following release downstream of a hydropower station. In E. B. Thorstad, I. A. Fleming, \& T. F. Næsje, (Eds.), Aquatic Telemetry (pp. 31-37). Springer. https://doi.org/10.1007/978-94-017-0771-8_5

Larinier, M. (2008). Fish passage experience at small-scale hydro-electric power plants in France. Hydrobiologia, 609(1), 97-108. https://doi. org/10.1007/s10750-008-9398-9
Larinier, M., Dumond, L., Lagarrigue, T., Frey, A., \& Travade, F. (2020). Performance of a large partial-depth guide wall to divert downstream migrating Atlantic salmon smolts at Tuilières dam, Dordogne River. Knowledge \& Management of Aquatic Ecosystems, 421, 15. https://doi.org/10.1051/kmae/2020010

Larinier, M., \& Travade, F. (2002). Downstream migration: problems and facilities. Bulletin Français de la Pêche et de la Pisciculture, 364(supplément), 181-207. https://doi.org/10.1051/kmae/2002102

Lothian, A. J., Newton, M., Barry, J., Walters, M., Miller, R. C., \& Adams, C. E. (2018). Migration pathways, speed and mortality of Atlantic salmon (Salmo salar) smolts in a Scottish river and the near-shore coastal marine environment. Ecology of Freshwater Fish, 27(2), 549558. https://doi.org/10.1111/eff.12369

Marschall, E. A., Mather, M. E., Parrish, D. L., Allison, G. W., \& McMenemy, J. R. (2011). Migration delays caused by anthropogenic barriers: Modeling dams, temperature, and success of migrating salmon smolts. Ecological Applications, 21(8), 3014-3031. https://doi. org/10.1890/10-0593.1

McCormick, S. D., Hansen, L. P., Quinn, T. P., \& Saunders, R. L. (1998). Movement, migration, and smolting of Atlantic salmon (Salmo salar). Canadian Journal of Fisheries and Aquatic Sciences, 55(S1), 77-92. https://doi.org/10.1139/d98-011

Moore, A., Privitera, L., Ives, M. J., Uzyczak, J., \& Beaumont, W. R. C. (2018). The effects of a small hydropower scheme on the migratory behaviour of Atlantic salmon Salmo salar smolts. Journal of Fish Biology, 93(3), 469-476. https://doi.org/10.1111/jfb.13660

Mueller, M., Sternecker, K., Milz, S., \& Geist, J. (2020). Assessing turbine passage effects on internal fish injury and delayed mortality using X-ray imaging. PeerJ, 8, e9977. https://doi.org/10.7717/peerj.9977

Newton, M., Barry, J., Dodd, J. A., Lucas, M. C., Boylan, P., \& Adams, C. E. (2019). A test of the cumulative effect of river weirs on downstream migration success, speed and mortality of Atlantic salmon (Salmo salar) smolts: An empirical study. Ecology of Freshwater Fish, 28(1), 176-186. https://doi.org/10.1111/eff.12441

Nilsson, C., Reidy, C. A., Dynesius, M., \& Revenga, C. (2005). Fragmentation and Flow regulation of the World's large river systems. Science, 308(5720), 405-408. https://doi.org/10.1126/scien ce. 1107887

Ovidio, M., Dierckx, A., Bunel, S., Grandry, L., Spronck, C., \& Benitez, J. P. (2017). Poor performance of a retrofitted downstream bypass revealed by the analysis of approaching behaviour in combination with a trapping system: retrofitted downstream bypass system. River Research and Applications, 33(1), 27-36. https://doi. org/10.1002/rra.3062

Ovidio, M., Enders, E. C., Hallot, E. J., Roy, M. L., Philippart, J. C., Petit, F., \& Roy, A. G. (2007). Mobility and home-range use of Atlantic salmon parr over short time scales. Aquatic Living Resources, 20, 95101. https://doi.org/10.1051/alr:2005020

Ovidio, M., Renardy, S., Dierckx, A., Nzau Matondo, B., \& Benitez, J.P. (2021). Improving bypass performance and passage success of Atlantic salmon smolts at an old fish-hostile hydroelectric power station: A challenging task. Ecological Engineering, 160, 106148. https://doi.org/10.1016/j.ecoleng.2021.106148

Ovidio, M., Sonny, D., Watthez, Q., Goffaux, D., Detrait, O., Orban, P., Nzau Matondo, B., Renardy, S., Dierckx, A., \& Benitez, J.-P. (2020). Evaluation of the performance of successive multispecies improved fishways to reconnect a rehabilitated river. Wetlands Ecology and Management, 28(4), 641-654. https://doi.org/10.1007/s11273020-09737-w

Parrish, D. L., Behnke, R. J., Gephard, S. R., McCormick, S. D., \& Reeves, G. H. (1998). Why aren't there more Atlantic salmon (Salmo salar)? Canadian Journal of Fisheries and Aquatic Sciences, 55(S1), 281-287. https://doi.org/10.1139/d98-012

Pauwels, I. S., Baeyens, R., Toming, G., Schneider, M., Buysse, D., Coeck, J., \& Tuhtan, J. A. (2020). Multi-species assessment of injury, 
mortality, and physical conditions during downstream passage through a large archimedes hydrodynamic screw (Albert Canal, Belgium). Sustainability, 12(20), 8722. https://doi.org/10.3390/ su12208722

Reitan, O., Hvidsten, N. A., \& Hansen, L. P. (1987). Bird predation on hatchery reared Atlantic salmon smolts, Salmo salar L., released in the River Eira, Norway. Fauna Norvegica, Series A, 8, 35-38.

Renardy, S., Benitez, J.-P., Tauzin, A., Dierckx, A., Nzau Matondo, B., \& Ovidio, M. (2020). How and where to pass? Atlantic salmon smolt's behaviour at a hydropower station offering multiple migration routes. Hydrobiologia, 847(2), 469-485. https://doi.org/10.1007/ s10750-019-04108-w

Renardy, S., Takriet, A., Benitez, J.-P., Dierckx, A., Baeyens, R., Coeck, J., Pauwels, I. S., Mouton, A., Archambeau, P., Dewals, B., Pirotton, M., Erpicum, S., \& Ovidio, M. (2021). Trying to choose the less bad route: Individual migratory behaviour of Atlantic salmon smolts (Salmo salar L.) approaching a bifurcation between a hydropower station and a navigation canal. Ecological Engineering, 169(3), https://doi.org/10.1016/j.ecoleng.2021.106304

Scruton, D. A., McKinley, R. S., Kouwen, N., Eddy, W., \& Booth, R. K. (2003). Improvement and optimization of fish guidance efficiency (FGE) at a behavioural fish protection system for downstream migrating Atlantic salmon (Salmo salar) smolts. River Research and Applications, 19(5-6), 605-617. https://doi.org/10.1002/rra.735

Stich, D. S., Bailey, M. M., \& Zydlewski, J. D. (2014). Survival of Atlantic salmon Salmo salar smolts through a hydropower complex: Smolt survival through a hydropower complex. Journal of Fish Biology, 85(4), 1074-1096. https://doi.org/10.1111/jfb.12483

Szabo-Meszaros, M., Forseth, T., Baktoft, H., Fjeldstad, H., Silva, A T., Gjelland, K. Ø., Økland, F., Uglem, I., \& Alfredsen, K. (2019). Modelling mitigation measures for smolt migration at dammed river sections. Ecohydrology, 12(7), https://doi.org/10.1002/eco.2131

Teichert, N., Benitez, J. P., Dierckx, A., Tétard, S., de Oliveira, E., Trancart, T., Feunteun, E., \& Ovidio, M. (2020). Development of an accurate model to predict the phenology of Atlantic salmon smolt spring migration. Aquatic Conservation: Marine and Freshwater Ecosystems, 30(8), 1552-1565. https://doi.org/10.1002/aqc.3382

Thorstad, E. B., Havn, T. B., Saether, S. A., Heermann, L., Teichert, M. A. K., Diserud, O. H., Tambets, M., Borcherding, J., \& Økland, F. (2017). Survival and behaviour of Atlantic salmon smolts passing a run-ofriver hydropower facility with a movable bulb turbine. Fisheries Management and Ecology, 24(3), 199-207. https://doi.org/10.1111/ fme.12216
Thorstad, E. B., Whoriskey, F., Uglem, I., Moore, A., Rikardsen, A. H., \& Finstad, B. (2012). A critical life stage of the Atlantic salmon Salmo salar: Behaviour and survival during the smolt and initial postsmolt migration. Journal of Fish Biology, 81(2), 500-542. https://doi. org/10.1111/j.1095-8649.2012.03370.x

Tomanova, S., Courret, D., Alric, A., De Oliveira, E., Lagarrigue, T., \& Tétard, S. (2018). Protecting efficiently sea-migrating salmon smolts from entering hydropower plant turbines with inclined or oriented low bar spacing racks. Ecological Engineering, 122, 143152. https://doi.org/10.1016/j.ecoleng.2018.07.034

Tomanova, S., Courret, D., Richard, S., Tedesco, P. A., Mataix, V., Frey, A., Lagarrigue, T., Chatellier, L., \& Tétard, S. (2021). Protecting the downstream migration of salmon smolts from hydroelectric power plants with inclined racks and optimized bypass water discharge. Journal of Environmental Management, 284, 112012. https://doi. org/10.1016/j.jenvman.2021.112012

Urke, H. A., Kristensen, T., Ulvund, J. B., \& Alfredsen, J. A. (2013). Riverine and fjord migration of wild and hatchery-reared Atlantic salmon smolts. Fisheries Management and Ecology, 20(6), 544-552. https://doi.org/10.1111/fme.12042

Vikström, L., Leonardsson, K., Leander, J., Shry, S., Calles, O., \& Hellström, G. (2020). Validation of Francis-Kaplan Turbine Blade Strike Models for Adult and Juvenile Atlantic Salmon (Salmo Salar L.) and Anadromous Brown Trout (Salmo Trutta L.) passing high head turbines. Sustainability, 12(16), 6384. https://doi.org/10.3390/su121 66384

Williams, J. G., Armstrong, G., Katopodis, C., Larinier, M., \& Travade, F. (2012). Thinking like a fish: a key ingredient for development of effective fish passage facilities at river obstructions. River Research and Applications, 28(4), 407-417. https://doi.org/10.1002/rra.1551

How to cite this article: Renardy, S., Colson, D., Benitez, J.-P., Dierckx, A., Goffaux, D., Sabbe, J., Rabouan, A., Detrait, O., Nzau Matondo, B., Sonny, D., \& Ovidio, M. (2022). Migration behaviour of Atlantic salmon smolts (Salmo salar L.) in a short and highly fragmented gravel-bed river stretch. Ecology of Freshwater Fish, 31, 499-514. https://doi.org/10.1111/ eff.12646 